University of Nebraska - Lincoln

DigitalCommons@University of Nebraska - Lincoln

Faculty Publications: Political Science

Political Science, Department of

2011

Plato's Heroic Vision: The Difficult Choices of the Socratic Life

Ari Kohen

University of Nebraska-Lincoln, akohen2@unl.edu

Follow this and additional works at: https://digitalcommons.unl.edu/poliscifacpub

Part of the Political Science Commons

Kohen, Ari, "Plato's Heroic Vision: The Difficult Choices of the Socratic Life" (2011). Faculty Publications: Political Science. 45.

https://digitalcommons.unl.edu/poliscifacpub/45

This Article is brought to you for free and open access by the Political Science, Department of at DigitalCommons@University of Nebraska - Lincoln. It has been accepted for inclusion in Faculty Publications: Political Science by an authorized administrator of DigitalCommons@University of Nebraska - Lincoln. 


\title{
PLATO'S HEROIC VISION: \\ THE DIFFICULT CHOICES OF THE SOCRATIC LIFE
}

\author{
Ari Kohen ${ }^{I}$
}

\begin{abstract}
Faced with charges of impiety and corruption of the youth, Socrates attempts a defence designed to vindicate the philosophic way of life. In this he seems to be successful, as Socrates is today highly regarded for his description of the good life and for his unwillingness to live any other sort of life, a position that is most obviously exemplified by his defence in the Apology. After his sentencing, Socrates' arguments and actions - in the Crito and the Phaedo - also lend considerable support to the idea that the philosopher is committed to living a particularly good sort of life. While the sequence of dialogues that culminates in Socrates' execution might seem to be the most obviously critical of the life of the philosopher, these dialogues actually serve to enshrine the character of Socrates as the quintessential moral hero.
\end{abstract}

Socrates wanted to die: not Athens, but he himself chose the hemlock; he forced Athens to sentence him. ${ }^{2}$

The dying Socrates became the new ideal, never seen before, of noble Greek youths. ${ }^{3}$

\section{Introduction}

There are few, if any, who praise the Athenians for having convicted and executed Socrates. Such an argument is particularly difficult to find in the West today, where freedom of thought and expression reign supreme. Indeed, to suggest that Socrates truly was guilty of corrupting the youth of Athens and of not believing in the gods of the city is a great deal less controversial than agreeing with the Athenians that death is an appropriate punishment for those actions. While he might well have been guilty of the crimes for which he stood accused, few believe these things ought to be crimes in the first place. Thus, when I teach Plato's Apology, my students are generally outraged by the fact that impiety was a capital crime, and that the first political philosopher went to his death largely for encouraging the Athenians to question authority and received opinion. Yet it is a rather large leap from that position to one that extols Socrates' virtues or to the belief that Socrates is someone to be emulated.

${ }^{1}$ Schlesinger Associate Professor of Political Science and Director of the Forsythe Family Program on Human Rights and Humanitarian Affairs at the University of Nebraska - Lincoln, 511 Oldfather Hall, Lincoln, Nebraska 68502, USA. Email: akohen2@unl.edu

${ }^{2}$ Friedrich Nietzsche, Twilight of the Idols, in The Portable Nietzsche, ed. and trans. Walter Kaufmann (New York, 1968), p. 479.

${ }^{3}$ Friedrich Nietzsche, The Birth of Tragedy, in Basic Writings of Nietzsche, ed. and trans. Walter Kaufmann (New York, 1992), p. 89.

POLIS. Vol. 28. No. 1, 2011 
In general, the classic portrait of Socrates is not a particularly inspiring one; in the dialogues that deal with his trial and execution, he treats his accusers with scorn, he speaks ironically to his interlocutors (his friends and even his jurors), and his arguments often seem designed to confuse rather than to persuade. For all of that, however, I want to argue that the Platonic Socrates especially of the Apology, Crito and Phaedo - is a character meant to do much more than simply move readers to feelings of great sympathy; rather, he is carefully crafted to serve as a new model for heroic behaviour that ought to be emulated. Indeed, his speeches and deeds - including the often confusing and unpersuasive arguments - call attention to the self-sacrifice of Socrates on behalf of his friends, the Athenians who condemn him and, more broadly, the life of the mind.

Given the unflattering picture that emerges in several dialogues, a good deal must be said in order to defend the claim that Socrates is a character who is designed to engender feelings of admiration. Allan Bloom notes that, in the Clouds, Aristophanes presents the philosopher as one who

spends his life investigating nature, worrying about gnats and stars, denying the existence of the gods because they are not to be found in nature ... His companions are pale-faced young men totally devoid of common sense. In this academy, which has established itself in the free atmosphere of Athens, these eccentrics carry on their activities without appearing to be other than harmless cranks. ${ }^{4}$

For Bloom, this portrayal is not overly problematic; one can celebrate and seek to emulate the life of Socrates while also laughing along with Aristophanes. Indeed, there is undeniably something amusing about the Clouds; in part, it is that 'Aristophanes recaptures for us the absurdity of a grown man who spends his time thinking about gnats' anuses'. 5 That said, many readers are seriously troubled by the connection between the charges levelled against Socrates in the Clouds and those that ultimately resulted in his execution $;^{6}$ and, of course, Aristophanes' portrayal is not the only one that paints Socrates in a less than flattering light.

In several of Plato's dialogues, Socrates is described by his interlocutors as weak, cowardly and disingenuous. Perhaps the most famous negative description is put forward by Callicles in the Gorgias (480a-487e). There, the life of the philosopher is subjected to serious scorn and ridicule. Angela Hobbs aptly describes Callicles' devastating critique:

The adult philosopher is utterly ignorant of the ways of the world, and entirely inexperienced in the pleasures, desires and characters of men. If he

${ }^{4}$ Allan Bloom, The Closing of the American Mind (New York, 1987), p. 269.

5 lbid., p. 270.

${ }^{6}$ While Socrates is made to look ridiculous rather than dangerous in The Clouds, he is also clearly identified as someone who encourages sons to challenge the authority of fathers and who sees no place in the world for the gods of Athens. 
ever has to engage in any public business, he is thus bound to make a fool of himself; he is equally bound to lack manliness, since he spends his days huddled in a corner with a few callow youths, avoiding the social centres where, as Homer notes, men win glory. Unable to protect himself or his own if wrongfully accused, he is both a boy amongst men and a slave amongst the free.?

It is noteworthy that Callicles directly mentions the inability of the philosopher to defend himself against potential accusers or to act heroically. Plato will need to answer both of these challenges in order to present the philosophic way of life as one worthy of emulation. In addition to this denunciation, the Republic also presents a critique of Socrates' character. There, Thrasymachus chastises Socrates for talking nonsense, debating in an inane manner, and being ironic (336c-d). Further, when Socrates begins to question his definition of justice as the advantage of the stronger, Thrasymachus retorts: 'You are disgusting, Socrates ... You take hold of the argument in the way you can work it the most harm' $(338 \mathrm{~d}){ }^{8}$ While we might dismiss as sour grapes the obvious contempt for Socrates that Thrasymachus displays, it is also noteworthy that Book I of the Republic ends with the former unable to convincingly refute the argument about justice made by the latter. ${ }^{9}$

In so many ways, then, Socrates seems to be the central figure in a cautionary tale that fathers might present to their sons. Given these critiques, what about him might be seen as heroic or worthy of emulation? In this article, I put forward an answer to this question through an exploration of the three Platonic dialogues that deal with Socrates' trial and execution. Faced with charges of impiety and corruption of the youth, Socrates attempts a defence designed to vindicate the philosophic way of life. In this he seems to be successful, as Socrates is today highly regarded for his description of the good life and for his unwillingness to live any other sort of life, a position that is most obviously exemplified by his defence in the Apology. After his sentencing, Socrates' arguments and actions - in the Crito and the Phaedo - also lend considerable support to the idea that the philosopher is committed to

\footnotetext{
${ }^{7}$ Angela Hobbs, Plato and the Hero: Courage, Manliness and the Impersonal Good (Cambridge, 2000), p. 139.

${ }^{8}$ Hobbs connects the critiques of Thrasymachus and Callicles in an interesting way, arguing that both represent spiritedness ( $\theta 0 \mu$ ó 5 thumos) in their respective dialogues: 'In Thrasymachus ... we see what happens when the thumoeidic lion of the Gorgias does not manage to break through its social bonds, but remains imprisoned in a society it despises' (ibid., p. 170).

${ }^{9}$ Later, in Book VI, Adeimantus imagines someone who would argue that 'of all those who start out on philosophy - not those who take it up for the sake of getting educated when they are young and then drop it, but those who linger in it for a longer time most become quite queer, not to say completely vicious; while the ones who seem perfectly decent, do nevertheless suffer at least one consequence of the practice you are praising - they become useless to the cities' (487d).
} 
living a particularly good sort of life. While the sequence of dialogues that culminates in Socrates' execution might seem to be the most obviously critical of the life of the philosopher, I want to argue that these dialogues actually serve to enshrine the character of Socrates as the quintessential moral hero.

Plato manages to turn the ignoble death of his mentor into a virtuous triumph for two reasons: first, he suggests that Socrates has an intimate understanding - perhaps even an appreciation - of his mortality and actively chooses to die. Secondly, he demonstrates that - in choosing to give up his life - Socrates sacrifices himself for those with whom he identifies, both his friends and even the Athenians at large who seem to be his enemies. He explains his decision to several of his students in ways that set an example of proper decision-making and also encourage them to continue to see the life of the philosopher as choice-worthy. In so depicting Socrates' trial and execution, Plato establishes his mentor as a moral hero who gives up his life to benefit others and who demonstrates that the kind of life one lives - rather than its duration - is of primary importance.

\section{The Trial of Socrates}

The arguments found in Plato's Apology are well-known and much-discussed, as is the idea that Socrates' character is crafted to be seen as a martyred hero. ${ }^{10}$ There is little debate about whether Socrates defended himself successfully against the charges that he faced, even if Socrates himself wants to debate why his accusers have brought him to trial. Similarly, few people seriously question whether Socrates believes that his jury will accept his proposed punishment after convicting him; instead, most assume that he is either speaking ironically or actively seeking the death penalty proposed by his accusers. ${ }^{11}$ Somewhat less well-worn, however, is a discussion of Socrates' initial defence and so it is to that discussion that I turn in this section, as I want to suggest that

${ }^{10}$ But see Thomas C. Brickhouse and Nicholas D. Smith, Socrates on Trial (Princeton, 1989), who attempt to show 'that his principles require Socrates to do everything in his power, consistent with those principles, to gain his acquittal. If we are right, they allow him neither to seek martyrdom nor to scorn the proceedings with indifference' (p. 9).

11 Socrates asks, '[w]hat, then, is fitting for a poor man, a benefactor, who needs to have leisure to exhort you?' and then argues that '[t]here is nothing more fitting, men of Athens, than for such a man to be given his meals in the Prytaneum, much more so than if any of you has won a victory at Olympia with a horse or a two- or four-horse chariot. For he makes you seem to be happy, while I make you be so; and he is not in need of sustenance, while I am in need of it' (36d-e). But it is quite clear that the jurors, who have just convicted him of impiety, will not choose to reward Socrates in the way they traditionally reward the city's great champions. In failing to provide an adequate alternative punishment to the one proposed by Meletus, Socrates confirms the position that he advocates throughout his trial, namely that only his death will put a stop to his philosophizing. 
Socrates' defence cannot possibly succeed in refuting the charge of impiety (or of corrupting the youth, which stemmed from it) and is not intended to do so.

Socrates' contemporaries believed that philosophy was a useless and dangerous activity; indeed, the danger of the philosopher stemmed, at least in part, from his uselessness. The philosopher, they argued, was thoroughly self-interested and was, therefore, not a contributing member of the political community. ${ }^{12}$ In the Clouds, Socrates is characterized by his selfish concerns for others' money and his own reputation. He and his students spend their time engaged in outrageous arguments and the examination of the things in the heavens and below the earth, rather than with those things - like working, governing or fighting - that would fall within the traditional purview of other Athenians. ${ }^{13}$ In contemplating the eternal things, Socrates does little if anything - that would serve to benefit his community and challenges the very idea that human beings should only concern themselves with their own small world. Worse still, in discussing ephemeral topics with the youth of Athens in the agora, Socrates might come to be seen as a role model for these young Athenians to emulate. His endeavour - amusing and provocative as it is - actually seems designed to ensure this possibility, as he questions the best-known and most-respected men of Athens, and systematically displays how little they truly know about the very topics in which they claim expertise. In doing so, he bolsters his own reputation for wisdom while denigrating all others. Thus, the philosopher is not simply a lazy or arrogant annoyance, one who challenges received opinion while contributing precious little of substance: he is also a potential subversive. If he successfully presents his way of life as worthwhile, the consequences for Athens could be disastrous. A good number of young men might choose to follow the example of Socrates and thereby neglect their duties as citizens. While Socrates would not regard this behaviour as a corruption of the youth, it seems clear that his jurors should. Yet Socrates agrees that the youth follow him, but he says that they do so of their own free will. He takes pains to demonstrate that he does not charge

12 Of course, in the immediate aftermath of the Peloponnesian War and the rule of the Thirty Tyrants, the Athenians of $399 \mathrm{BC}$ might have had other reasons to be suspicious of Socrates. As Brickhouse and Smith (Socrates on Trial, pp. 20-1) note, 'a number of his associates were men with extremely unsavory reputations at the time Socrates was indicted. Plato's uncle, Charmides, for example, was one of the Thirty, and was recognized as one of Socrates' admirers ... Even worse, Socrates may also have been linked to Critias, whose iron-fisted actions as the leader of the Thirty made his name the emblem of their infamy... Yet another potentially dangerous association may have been the one with Alcibiades [infamous for proposing the ill-fated Sicilian Expedition in 415-13 BC, he fled to the Spartan side in the face of accusations of sacrilege in Athens] . . . His damaging association with Socrates ... may have lingered in the jurors' minds'.

${ }^{13}$ Aristophanes, Clouds, in Four Texts on Socrates, trans. Thomas G. West and Grace Starry West (Ithaca, 1984), pp. 187-206. 
them for the lessons they learn and proceeds to argue that his influence does not corrupt them. Indeed, neither the parents nor the children who are directly concerned have ever come forward to argue against him and even now, at his trial, his accusers cannot bring forward any witnesses against him (33e-34a). Therefore, he argues, the parents must not actually believe their children to be corrupt and the children with whom he spoke in their youth must not have grown into corrupt adults.

Whether or not the jurors could conceivably be convinced by this argument, it seems clear that anyone who spends a significant amount of time with Socrates probably runs the risk of corruption. After all, his stated goal in the Republic is to demonstrate the virtue of living a life devoted to philosophy, and he clearly reiterates that position during his trial. Anyone who might be convinced - either by his arguments or by his lifestyle - would be following an example that is distinctly troubling for Athens. For in living a life devoted to questioning and thinking about what happens in those places that are above and below the earth, Socrates wants to subject Olympus and Hades to the same sort of examination for which he is known in Athens. But this amounts to claiming that the world of the gods can be made intelligible to human beings in the same way as the natural world, which probably ought to be read as a direct challenge to the gods. After all, the natural world around us is clearly observable and measurable, while the world of the gods is considered to be mysterious and so presumably unknowable. In asking questions about the realm of the gods, Socrates is probably blaspheming; in claiming that he might make sense of it he is unquestionably displaying that classic tragic vice, hubris. While we might well question whether Aristophanes' portrayal of Socrates is a fair or accurate one, it is noteworthy that Plato's Socrates is undoubtedly acting either blasphemously or hubristically in the Apology as well. ${ }^{14}$

In his own defence against the charge of impiety, Socrates tells an unusual story about how he came to be on trial (21b-23e). He argues that Chaerephon, a deceased friend of his who appeared in the Clouds and was also well-known to the jurors, once visited the Oracle at Delphi and was told there that Socrates was the wisest man. Upon hearing what he perceives as an outrageous claim about his own intelligence, Socrates sets out on a quest to find wiser men than himself. He is quite clear that he doesn't believe the words of the Oracle; thus, he decides that he must now spend his time publicly interviewing the most respected men of Athens in order to demonstrate the inaccuracy of the Oracle's

14 Socrates seems to concede, in the Phaedo, that he might have been, at one time in his life, guilty of one of the Aristophanic charges against him: 'When I was a young man, Cebes, I was most amazingly interested in the lore which they call natural philosophy. For I thought it magnificent to know the causes of everything, why it comes into being and why it is destroyed and why it exists ... I considered the destructions of these things, and what happens about heaven and earth' $(96 a-c)$. 
claim. He begins with the politicians, moves next to the poets, and finally concludes with the artisans. Unfortunately - though perhaps unsurprisingly Socrates discovers that 'those with the best reputations seemed to me nearly the most deficient' (22a). Of course, in asking questions of those people who are considered wise by everyone and then demonstrating their shortcomings, Socrates recognizes that he is not winning any friends amongst the men of Athens. Despite both the personal and financial costs to him, he cannot give up his examination of those men who are purported to be wise, as he argues that his activity is done in the service of Apollo.

Brickhouse and Smith view Socrates' mission as a pious one, as 'Socrates' attempt to refute the apparent meaning of the oracle only reinforces the view that he sees piety as requiring that he always make "the god's business" take first priority'. ${ }^{15}$ The trouble with this argument - and with the entire story that Socrates tells about Chaerephon - is that human beings simply do not have the option of disputing the Delphic Oracle. As is well-known from the majority of Greek tragedy - most notably the tale of Oedipus - horrible misfortune always ensues when mortals attempt to question what the gods have decreed. As Michael Zuckert notes: 'Like Oedipus, he sets off on his "wanderings" in order to show that the oracle is false. Socrates" "service to the god" consists in an Oedipean rebellion against the god. ${ }^{16}$ Just as Oedipus cannot outrun his fate, it seems like a tragic mistake for Socrates to question the accuracy of the Oracle. In defending himself with this story about what he sees as his overwhelming devotion to Apollo, Socrates seems to be embracing the charge of impiety by displaying his hubristic attitude (even if we might argue that he does so fairly subtly). His goal, in all that he has done, has always been to find a man wiser than himself. This quest both infuriates the individuals with whom he speaks and also serves as a direct challenge to the validity of the Delphic Oracle. In other words, Socrates either acts with hubris by trying to prove the god wrong or else he is guilty of impiety, as charged, because he does not believe in the god's omniscience. Regardless of whether the former or the latter is correct - and it seems impossible to decide which is the actual position that Socrates takes - both are incredibly dangerous and have obviously negative implications for the outcome of his trial.

In thinking through the charge of impiety and Socrates' defence against it, one would be hard-pressed to argue that the philosopher is successful in demonstrating his innocence. Yet it is also important to note that Socrates seems less interested in proving that he is pious than a defendant probably ought to be. Instead, a good portion of his defence - after the story described above is given over to a demonstration of the ignorance of his accusers, as well as their envy and personal animosity towards him. Thomas West argues that,

15 Brickhouse and Smith, Socrates on Trial, p. 96.

${ }^{16}$ Michael Zuckert, 'Rationalism \& Political Responsibility: Just Speech \& Just Deed in the Clouds and the Apology of Socrates', Polity, 17.2 (1984), p. 284. 
instead of attempting to defend himself against the charges, Socrates jokes with Meletus, who 'cannot help being ridiculous because he woodenly persists in trying to be serious'. ${ }^{17}$ While he then pronounces his answer to Meletus 'sufficient', he immediately claims that 'this is what will convict me, if it does convict me: not Meletus or Anytus, but the slander and envy of the many. This has convicted many other good men too, and I suppose it will also convict me' (28a-b). Thus, although he might be successful in highlighting the true motivation behind his trial, namely that Meletus, Anytus and even his jurors desire that he be publicly punished, it is also possible to argue that neither Socrates' behaviour nor that of his accusers prior to the trial ultimately account for his conviction. ${ }^{18}$ Indeed, it seems just as likely that the jurors find him guilty by virtue of his behaviour during the trial. ${ }^{19}$ After all, much of his defence is spent reminding his jurors that he is allegedly the wisest man in the world and certainly wiser than they are. The remainder focuses the attention of the jury on the consequences of the trial's outcome, for Socrates effectively raises the stakes for himself and for the city before the jurors have even considered whether he should be judged guilty or innocent.

While any reader of the Apology would already know that the historical Socrates was convicted and ultimately executed, it is unusual that Plato's Socrates seems to force the hand of the jury in the matter even as he should be defending himself. Rather than focusing solely on the question of his guilt or innocence, Socrates argues that the jury must either find his actions blameless or kill him. Central to this point is Socrates' argument that he has not intentionally harmed anyone and that, if he has done any unintentional harm, he did

17 Thomas G. West, Plato's Apology of Socrates: An Interpretation, with a New Translation (Ithaca, 1979), p. 147.

18 There is, of course, much debate about the proximate cause of Socrates' trial, but it seems clear that it could have been avoided had Socrates desired. Crito suggests as much (45e), as does Xenophon (Socrates' Defence, in Conversations of Socrates, trans. Hugh Tredennick and Robin Waterfield, ed. Robin Waterfield (New York, 1990), pp. 43, 46). Further, in the Meno, Socrates seems determined to make an enemy of Anytus, who would later become one of his principal accusers (92b-94a).

19 This runs counter, once again, to the interpretation of Brickhouse and Smith, who argue that "the arguments Socrates develops during his interrogation of Meletus are designed not merely, as other commentators have claimed, to confuse Meletus, and thus discredit him before the jury, but rather to refute the legal charges themselves by showing that they are based upon incoherent and thus indefensible prejudices' (Brickhouse and Smith, Socrates on Trial, p. 110). If it is the case that Socrates seeks to successfully refute the charges, it is surprising - given all that I have argued to this point - that he takes the tack he does. Brickhouse and Smith base their conclusion that Socrates believed in the gods of the city on the fact that '[i]f he did not accept customary religion, his leaving the impression that he did would cause him to run afoul of his mission [to tell the truth]; and there is no compelling reason to suppose that he did not accept it' (ibid., p. 127). All of this, of course, requires that Socrates is straightforwardly pious and always says exactly what he means, two points that I challenge throughout. 
so only with the hope of teaching others how to live virtuously. Given his view of both his innocence and the morality of his actions, Socrates believes that he cannot do anything other than what he has done. Even more than arguing for the perceived rightness of his actions, however, Socrates suggests that he will not flatter his jurors or seek to arouse their sympathy in ways that might have been expected. To do so would be inappropriate for someone with the reputation for virtue that he believes he possesses. V.J. Gray writes: 'Socrates does not conform to the accepted psychology of a man on trial for his life. He preferred to die by megalēgoria [ $\mu \varepsilon \gamma \alpha \lambda \eta \gamma о \rho i \alpha$; lit. 'big talk', highmindedness, boastfulness] than live by appeasement. ${ }^{20}$ Though Socrates does make reference to his military service on behalf of the city and also to his poverty as proof that he does not charge the youth who learn from him, N.A. Greenberg argues that his 'major defence, whether the result of Machiavellian planning ... or the result of an absolute confidence in the rightness of his past life ... is a tremendous stipulation in the form of a counterchallenge flung at the jurors: Either kill me or acquit me'. ${ }^{21}$ The increased risk that he faces from this gamble is calculated to make clear to the jury that Socrates means what he says. He does this by neglecting an actual defence, as described above, and by arguing that he will not back down by altering his behaviour. As he says:

So that not even if you let me go now and if you disobey Anytus - who said that either I should not have been brought in here at the beginning, or, since I was brought in, that it is not possible not to kill me (he said before you that if I am acquitted, soon your sons, pursuing what Socrates teaches, will all be completely corrupted) - if you would say to me with regard to this, 'Socrates, for now we will not obey Anytus; we will let you go, but on this condition: that you no longer spend time in this investigation or philosophize; and if you are caught still doing this, you will die' - if you would let me go, then, as I said, on these conditions, I would say to you, 'I, men of Athens, salute you and love you, but I will obey the god rather than you; and as long as I breathe and am able to, I will certainly not stop philosophizing ...' $(29 \mathrm{c}-\mathrm{d})$.

In other words, the only way for the city to ensure that Socrates will desist from philosophizing is by executing him; more traditional punishments like exile or a steep fine - would be unacceptable both to him and to them.

Indeed, Socrates spends a great deal of time and energy demonstrating that he does not fear the death that might well result from the gamble he takes. The tack that he takes with regard to dying is straightforward and fits nicely with his position about the virtues of the philosophical life. Socrates notes that no one knows what happens to people after they die and, for that reason, most

${ }^{20}$ V.J. Gray, 'Xenophon's Defense of Socrates: The Rhetorical Background to the Socratic Problem', Classical Quarterly, 39.1 (1989), p. 139.

${ }^{21}$ N.A. Greenberg, 'Socrates' Choice in the Crito', Harvard Studies in Classical Philology, 7 (1965), p. 70. 
people - fearing the unknown - fear death. The philosopher, however, is principally concerned with examining the unknown and so, rather than fearing death, he might well anticipate the unlocking of its mysteries. As he says:

to fear death, men, is in fact nothing other than to seem to be wise, but not to be so. For it is to seem to know what one does not know: no one knows whether death does not even happen to be the greatest of all goods for the human being; but people fear it as though they knew well that it is the greatest of evils (29a).

While Socrates will speak to this point in further detail in both the Crito and the Phaedo, he notes here that death is the eventual fate of every living thing and, as a consequence, one might consider how best to die. Rather than hoping to squeeze a few more years of life from his jurors by pleading with them or bringing his family forward on his behalf, Socrates argues that

as to reputation, mine and yours and the whole city's, to me it does not seem to be noble for me to do any of these things ... I have often seen some who are just like this when they are judged: although they are reputed to be something, they do wondrous deeds, since they suppose that they will suffer something terrible if they die - as though they would be immortal if you did not kill them (34e-35a).

This line of thought, characterized by Greenberg as choosing to live "not life, but a good life', is an important component of my argument that Socrates' behaviour should be regarded as distinctly heroic. ${ }^{22}$ Because he probably could avoid death and instead chooses to embrace it, Socrates is able to make a statement with his death. As Costica Bradatan points out, 'Socrates' death was the most effective means of persuasion he ever used, and over the centuries he has come to be venerated not so much for what he did when he was alive, but for the way in which he died'. ${ }^{23}$

That said, Bradatan puts forward a reading of Socrates' aggressive stance towards his jurors that is quite at odds with the one I have been advocating: 'By the age of seventy, one has grown deep enough into the world and the world has grown deep into one; any separation cannot but be painful, so Socrates had good reason for being afraid of dying., ${ }^{24}$ Thus, Socrates is exceptionally heroic in electing to die now rather than later. For Bradatan, 'a Socrates who had to make efforts to overcome his fear of death, who had to find his courage in the depths of his fear, is even more glorious' ${ }^{25}$ While it is quite likely that many (and perhaps most) septuagenarians fear death, it is noteworthy that the Platonic Socrates repeatedly tells us that he does not. For

22 Ibid., p. 56.

${ }^{23}$ Costica Bradatan, 'Philosophy as an Art of Dying', The European Legacy, 12.5 (2007), p. 589.

${ }^{24}$ Ibid., p. 591.

25 Ibid. 
Bradatan this amounts to excessive protestation that must be a signpost of his concern: 'Socrates is simply too insistent on his not being afraid of death not to draw our attention to it' ${ }^{26}$ The more straightforward reading, however, is one that takes Socrates at his word: he tells his jurors that he does not fear death not to convince himself, but because he wants to impress upon them that he truly does not. ${ }^{27} \mathrm{Of}$ course, on either reading, there is something distinctly impressive about Socrates. As I argue, Plato provides his readers with a role model who faces the unknown without trepidation, even putting on a defence that is very likely to lead to his execution. Further, his arguments about death and his actions surrounding his impending execution - in the Crito and the Phaedo, the jailhouse dialogues - seem to lend considerable support to this claim.

\section{II \\ The Possibility of Escaping Fate}

The Crito is perhaps best known for Socrates' argument that one must obey the Laws. He makes this case in a jailhouse discussion with his friend Crito, who actively seeks a way to mitigate the punishment that Socrates faces in the aftermath of his unsuccessful defence. While Crito is frustrated that Socrates has placed himself - and, by extension, all of his friends - in this situation in the first place, he is not above resorting to extrajudicial means to keep the philosopher alive. The possibility of bribery, escape and exile are all raised in the course of the dialogue, but Socrates cannot be turned from the path he has chosen. For Greenberg, this amounts to a distinction between the way practical and impractical men choose to approach a problem:

Crito takes a practical view of the situation. In his opinion, the trial should have been avoided or at least conducted differently, but all that is past. At the moment, as he sees it, Socrates has a choice between certain death and the attempt to escape, and he argues strongly for the latter ... For Socrates, the impractical man, it becomes important not only to defend his decision to remain and die, but also to defend his past decisions and actions, for the present and the past are closely and indissolubly connected for him. ${ }^{28}$

Whether or not we view the Socratic position as impractical, it is clear that the philosopher is very much driven, in the Crito, by arguments he made previously.

26 Ibid.

${ }^{27}$ I adopt this reading because it is, I think, also confirmed in the Crito (43b-c) and the Phaedo (58e), where Phaedo tells Echecrates that 'the man seemed happy to me ... in bearing and in speech. How fearlessly and nobly he met his end!'. As Greenberg notes, 'Crito is amazed at how easily and tranquilly Socrates conducts himself in a situation which Crito considers to be a calamity. Socrates replies that he is acting as any man of his years should, but Crito (and Plato) points out that most old men do not behave in this manner' (Greenberg, 'Socrates' Choice in the Crito', p. 48).

${ }^{28}$ Greenberg, 'Socrates' Choice in the Crito', p. 51. 
His claims, here, echo those made in both the Apology and the Republic, creating a coherent picture of Socrates that is heroic in his steadfast commitment to living justly.

The impending execution is an obvious evil to Crito and to most readers of Plato's dialogues, but for Socrates there are clearly several outcomes that would be worse still. Indeed, as he repeatedly argues in the Apology, 'the unexamined life is not worth living for a human being' (38a). This argument is reiterated in the Crito, as Socrates says that 'not living, but living well, is to be regarded as most important' ( $48 \mathrm{~b})$. That said, there is considerably less time spent in the Crito on making a case for living a particular sort of life, especially in comparison with the Apology or the Republic. Instead, the focus of Socrates' argument here is on whether or not it would be acceptable for him to escape the fate that has been decreed for him by the members of his jury.

The numerous points put forward by Crito seem to be at least moderately compelling, both on their own merits and also because readers would prefer that Socrates be saved from execution. The various claims are nicely articulated elsewhere and need not be rehearsed here in great detail. ${ }^{29}$ Suffice it to say that Crito approaches the problem from several angles and that Socrates eventually either ignores or deflects each one. At the centre of the dialogue, however, is the case for obeying the Laws, which forms the crux of Socrates' argument against escape. It is important to ask, then, whether Plato makes a compelling case on behalf of the Laws - which are personified here - or whether Socrates' decision not to resist his punishment rests on some other argument. To my mind, the idea that the Laws must always be obeyed simply does not hold up to scrutiny; thus I argue that Socrates has already decided to remain in prison prior to Crito's visit. Despite his good intentions, Crito's case is never seriously considered and Socrates' argument is meant to mollify his friend and instruct other like-minded Athenians.

In thinking through Socrates' discussion with Crito about the possibility of escape, it is important to note that he claims a willingness to try to escape if he can be persuaded that such an attempt would be right. At issue, then, is not the success or failure of the escape, but whether the proposed action itself (even if the attempted escape failed) can be shown to be the correct one. Thus, Socrates is not concerned with avoiding his punishment; he is, instead, interested in whether one can legitimately set out to subvert the law under which he has been convicted and sentenced. In the end, he argues that attempting to escape is impermissible because of the harm that would be caused by that attempt. The argument, then, revolves around the idea of harm and the claim that a just man ought not to harm anyone (an echo of the Republic). In the first place, it is clear that Crito is confused by Socrates' assertion that no one would be harmed if he decided to remain in prison and face execution. Leaving aside the question of whether Socrates himself ought to be considered (as Crito

${ }^{29}$ Ibid., pp. 48-9. 
would probably assume that he would be harmed by his own death, even though Socrates might not think so), there seem to be several people who would suffer from Socrates' death. Most obviously, Crito points out that the family and friends of the philosopher would be greatly injured by his execution. While his family would clearly suffer from the loss of husband and father, Crito also argues that the reputations of his friends - and his family too - would be harmed. By way of a response, Socrates says that 'these are considerations of those who easily kill and, if they could, would bring back to life again, acting mindlessly: namely the many' (48c). As Greenberg argues, this passage both conveys a deep contempt for those things - like reputation - that are prized by the masses, but also seems to fail to consider Crito's argument in any serious way. ${ }^{30}$ Is it not, in fact, the case that Socrates' friends and family will be harmed by his death, even if he is unwilling to agree that he is being personally harmed? And would the harm to these people not be substantially mitigated by his escape from the death penalty? While Socrates might be opposed to putting much weight on the loss of these things that are prized by the many, his friends and family will almost certainly feel differently in the aftermath of his execution. Crito is thoroughly perplexed by this discussion, as Socrates seems to ignore the harm done to himself, his friends and his family, while focusing on possible harm done to those who seek to execute him. In doing so, of course, Socrates clearly refutes the notion that he acts selfishly, for this would certainly be the time to think principally of oneself and one's loved ones if ever there was one. As Ernest J. Weinrib points out, 'now Socrates is suggesting, without so far explaining himself, that by escaping he will be harming precisely those who he least ought to. Those whom Socrates has in mind have an even stronger claim to immunity from harm than his friends and family, but who could those be? ? $^{31}$

As far as Socrates is concerned, the only serious consideration seems to be the harm that he would cause by attempting to escape from his judicial punishment. In the attempt, after all, Socrates would be expressing his opposition to the laws of Athens and this would presumably cause a great deal of harm (both to the laws and, by extension, to the city). Thus, the philosopher devotes a considerable amount of time in the Crito to thinking through the various ways in which his actions would do harm to the laws. To do so, he imagines a discussion where the Laws, personified, ask him:

By this deed that you are attempting, what do you think you're doing, if not destroying us Laws and the whole city, as far as it lies in you? Or does it seem possible to you for a city to continue to exist, and not to be overturned, in which the judgments that are reached have no strength, but are rendered ineffective and are corrupted by private men? (50a-b).

30 lbid., p. 60 .

${ }^{31}$ Ernest J. Weinrib, 'Obedience to the Law in Plato's Crito', American Journal of Jurisprudence, 27 (1982), p. 97. 
While these questions are certainly interesting ones, there are a number of problems that arise from them. Indeed, A.D. Woozley argues that 'the arguments given in Crito why it is wrong to break the law are interestingly bad rather than uninterestingly good' ${ }^{32}$ Thus, we might ask whether it is necessarily the case that any violation of the law spells disaster for the city as a whole, whether an attempted escape would thoroughly invalidate the power of the laws in general, and also whether it is therefore imperative to follow even unjust laws.

In responding to Crito, Socrates seems to be arguing something very similar to the idea that one cannot choose to obey the law when it stands in one's favour and then ignore it when it stands opposed. If the Athenians voted, in accordance with the laws, in favour of his execution, he must go along with that decision; after all, in all other decisions Socrates has respected the will of the voting majority without complaint. Thus the argument seems to be that if proper procedures are followed, one cannot now dispute the outcome. As the laws themselves ask,

are you not transgressing . . . your contracts and agreements with us, although you did not agree to them under necessity and were not deceived? Nor were you compelled to take counsel in a short time, but during seventy years in which you could have gone away if we were not satisfactory or if the agreements did not appear to be just to you (52d-e).

Further, Socrates - as a citizen of Athens - has benefited a great deal from the order, security and prosperity that can be traced back to the laws of the city. It might be human nature to complain when the laws now condone a judgment against him, but one must consider the fact that he never complained about any other judgment concerning others. Justice, then, would seem to demand that Socrates follow the dictates of the law in his own case, just as he has done in every other case.

But this is probbly not the central claim that he wants to make, for one might well argue that Socrates can safely disobey the laws in this case because the Athenians have arrived at an unjust outcome, even if they have followed the laws in doing so. ${ }^{33}$ Indeed, the essence of his discussion with Crito seems to be Socrates' opposition to exchanging injustice for injustice, which is

32 A.D. Woozley, Law and Obedience: The Arguments of Plato's Crito (Chapel Hill, 1979), p. vii.

${ }^{33}$ In opposition to this claim is the argument by Nathan Hanna in 'Socrates and Superiority', Southern Journal of Philosophy, 45.2 (2007), about the superiority of the city and its laws to its citizens. This argument, however, relies on an identification between Socrates and the personified laws that I do not find persuasive: 'The speech of the Laws puts Socrates' arguments on display, temporarily freed from any displeasing association with him, any distracting hint of immorality, arrogance, or self-indulgence, and powerfully drives home to the reader the injustice of the verdict and the moral carelessness and ignorance of the many who rendered it ... Most importantly, perhaps, they are calling on people to exercise political and moral responsibility - to respect the law 
further developed in his rebuttal of Polemarchus' claim, in the Republic, that a just person 'gives benefits and harms to friends and enemies' (332d). The argument about owing obedience to the laws of Athens, then, accords with the principle that one should not commit a wrong in response to a wrong. Of course, as Weinrib notes, this also implies 'the rejection of the converse popular notion that the doing of good is owed only to one's friends' ${ }^{34}$ While Socrates demonstrates for Polemarchus in the Republic that one cannot make a person more just by acting unjustly towards him, he seems also to conclude in the Crito that he must do good to those who condemn him and thereby provide them with further instruction. He speaks of honouring Athens and her laws, and in so doing, he is acting justly towards Athens as the city should be just to him, while refusing to do anything unjust. He believes that Athens has wronged him, but - as he loves Athens - he will not harm the city in return. There are two problems with this position, however. The first is that the principle under which Socrates has long been proceeding applies to people and not to laws. As Weinrib astutely argues,

the Laws are not persons but personifications, abstractions conjured up by Socrates and endowed with the power of speech, suffering, and action. The shift is unobtrusive but not insignificant, since the ... principle is derived from, and thus tied to, the supposition that there is something supremely human which is injured and destroyed by injustice in the same way that the body is destroyed by disease. ${ }^{35}$

Indeed, the Laws themselves accuse Socrates of working for their 'destruction', if he attempts to escape, rather than causing them 'harm' (50b). So Socrates has altered the argument in a way that would seemingly allow him to attempt an escape in his demonstration that such an attempt is impermissible.

The second problem, of course, is that the entire argument only holds if it is the case that disobedience to the Laws constitutes a harm to the city. The question of whether or not Socrates would do harm to Athens by disobeying the Laws in an attempt to save his life is not as easily assessed as it might initially appear. As noted above, Socrates argues that he loves Athens and will not exchange harm for harm with her citizens. An escape attempt would be a clear harm to Athens by undermining the power of her laws. This is the position put forward by the Laws themselves and Socrates seems to agree insofar as he by obeying it, to morally evaluate the law and work to change it by means of rational argument when they find it lacking, and to justly apply it' (p. 265). While this interpretation might fit well with a contemporary understanding of civil disobedience, on my reading it is not the argument made by the Laws and it also does not conform to the Superiority Thesis - that citizens must respect all laws because there is no equality of rights between laws and citizens - that Hanna puts forward throughout.

34 Weinrib, 'Obedience to the Law in Plato's Crito', p. 97.

${ }^{35} \mathrm{Ibid}$., p. 98. Weinrib also notes, rightly, that Socrates took pains in the Apology to prevent Meletus from conflating people and laws (24d-25a); to conflate the two here seems problematic, but Crito makes no mention of the inconsistency. 
refuses Crito's pleas. Yet Socrates does not appear to be nearly as caring in the Apology, where he argues that he loves Athens and also that his execution will damage the city by depriving her of someone who cares most deeply for her well-being (30c). Further, Athens will incur a negative reputation by executing him and her citizens will remain in ignorance. It is fair, then, to ask why he would refuse Crito's assistance in attempting to escape, if he truly loves Athens and believes that his death will have an adverse affect on her. The answer seems to rely on the argument that the laws have a special, parental relationship to the citizenry and that, in fact, one must treat the city and her laws with even more respect than one's parents $(50 \mathrm{e}-51 \mathrm{~b})$. Faced with these two competing claims, Socrates must choose between continuing to challenge the people of Athens by denouncing their unjust punishment and circumventing their laws, on the one hand, and respecting the traditional values of the city, on the other. As everyone knows, he will select the latter and accept his punishment.

That said, even this choice is more complicated than it appears, for Socrates only moments earlier told Crito that he did not respect the traditional judgments and values of the multitude. Why should he now respect the laws as the voice of the authority figures he has been challenging throughout his life? This seems especially surprising as the Laws themselves echo an unfair criticism of Socrates, about sons unnaturally beating their fathers, found in the Clouds. ${ }^{36}$ While the Laws seem to suggest that Socrates is liable to act unnaturally, they also seek to impress upon him that citizens ought not to do so. But, as Weinrib argues, '[t]he violation is ... of the tenet of popular morality that one should help one's friends and harm one's enemies. And it is precisely this tenet which Socrates was rejecting' ${ }^{37}$ Of course, in choosing to circumvent the laws of Athens, he would violate his own principle of not harming anyone, provided that one accepts that breaking the law will harm the Athenians. Even though 'Socrates' disobedience is expected because it is possible,

${ }^{36}$ In the Crito, the Laws say, '[n]ow with regard to your father ... justice was not equal to you, so that you didn't also do in return whatever you suffered: you didn't contradict him when he spoke badly of you, nor did you beat him in return when you were beaten, or do any other such thing' (50e-51a); and, in the Clouds, Pheidippides graduates from Socrates' 'thinkery' and then immediately proceeds to beat his father, Strepsiades, while arguing about the justice of doing so: 'PHEID. did you beat me when I was a boy?! STREP. Yes, I did. I was well-intentioned and concerned for you./ PHEID. Then tell me, isn't it also just for me likewise to be well-intentioned toward you and to beat you, since in fact to be well-intentioned is to beat? For why should your body be unchastised by blows, but not mine? ... And it's more appropriate for the old to weep than the young inasmuch as it's less just for them to do wrong./ STREP. But nowhere is it the law that the father suffer this./ PHEID. Wasn't he who first set down this law a man like you and me, and didn't he persuade those of long ago by speaking? Is it any less allowable for me too, then, to set down in turn for the future a novel law for sons to beat their fathers in return?' (1409-1425).

37 Weinrib, 'Obedience to the Law in Plato's Crito', p. 99. 
regardless of his innocence', his escape would constitute a harm by validating the Athenians' oversimplified understanding of justice as doing good to friends and harm to enemies.$^{38}$ In doing so, Socrates would accept the position that the Athenians are able to condemn him to death, on the one hand, and also - as Crito fears - to criticize his friends for failing to rescue him from that fate. Thus, in either case, Socrates seems to run headlong into one of the two principles he sought to impress upon Crito as being of grave importance. If he flees, he violates both principles by harming the Athenians insofar as their laws are circumvented and also by accepting the outlook of the many: 'just as they used the opportunity to convict him, so Socrates should use the opportunity to escape ${ }^{39}$ If he stays, he violates both principles by harming the Athenians insofar as they are deprived of him and also by accepting the outlook of the many: the laws 'are his friends and it would be ingratitude on his part to destroy, so far as in him lies, those who had rendered him such signal services in the past. He would be requiting benefit with harm' ${ }^{40}$

In an attempt to sort out what Socrates ought to do and why he chooses to remain, it is important to recall that he changes the terms of his second principle in the course of his discussion with Crito. Rather than avoiding all harm to all people, Socrates asks, '[i]f we go away from here without persuading the city, do we do evil to some - indeed, to those whom it should least be done to - or not?' (49e-50a). It seems, then, that Socrates is willing to compromise the principle a bit, acknowledging that some people will inevitably be harmed to some degree, though the harm might not be as serious as those people might imagine. On the one hand, it seems to be principally important to persuade the Athenians of the veracity of all that he has said prior to his conviction. The most obvious way to accomplish this task, of course, is to sacrifice himself, for he already averred - in the Apology — that he would not change his ways 'even if I were going to die many times' (30c). In order to demonstrate his stated commitment to living a good life, Socrates chooses to "express himself by the most radical means, namely, his own body, letting it die in a most spectacular manner, so that nobody could ignore or not "listen to" it'. ${ }^{41}$ Zuckert makes a very similar point: 'Socrates' dying for his philosophy, while upholding at once his own justice and the justice of the city, can prove to the Athenians that philosophy is not the sort of thing they suspect it to be. ${ }^{42}$ Yet, on the other hand, Socrates also seeks to provide for his friends even as he leaves them in a way that might harm them. Indeed, the arguments he makes in the final hours of his final day - chronicled in the Phaedo speak to this goal.

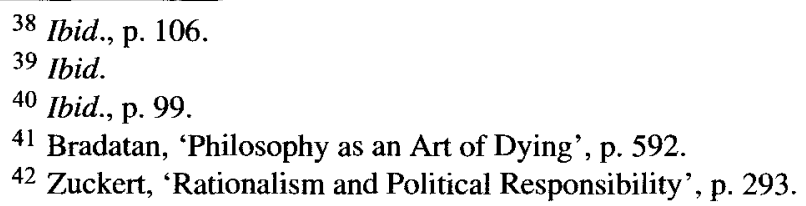




\section{III \\ The Longing for Immortality}

The Phaedo is a story within a story, as Phaedo - who was present at the execution - recounts to Echecrates - who was not - all that took place on the day of Socrates' death. There are several interesting points that might be discussed, including the philosopher's apparent lack of concern for his wife and children, and the fact that he has begun writing poetry despite vehemently arguing - especially in the Republic - against the influence of the poets. But the majority of the dialogue is devoted to a discussion of whether it makes sense to live a life devoted to philosophy, especially in the face of Socrates' execution that day. In order to make this case to two sceptical friends, Simmias and Cebes, Socrates puts forward a series of arguments to suggest both that the soul is immortal and that the philosopher will be rewarded after his death for his devotion to wisdom and justice.

In the first place, Socrates claims that death is actually the principal goal of the philosopher because only by dying can he attain true wisdom. As Eric Voegelin asserts: 'Under the aspect of death the life of the philosophical man becomes for Plato the practice of dying ... and, when the philosopher speaks as the representative of truth, he does so with the authority of death over the shortsightedness of life. ${ }^{43}$ For this position to be tenable, Socrates must go on to demonstrate that the soul will continue to exist, separately, after the death of the body. He begins by pointing out that, in all the time that a philosopher is alive, he is restricted from achieving his goal of truly knowing anything; Socrates' reason is that the senses are deceptive and the many bodily needs distract the philosopher unmercifully throughout life. He says:

So long as we have the body with us in our enquiry, and our soul is mixed up with so great an evil, we shall never attain sufficiently what we desire, and that, we say, is the truth ... Chief of all is that if we do have some leisure, and turn away from the body to speculate on something, in our searches it is everywhere interfering, it causes confusion and disturbance, and dazzles us so that it will not let us see the truth; so in fact we see that if we are ever to know anything purely we must get rid of it, and examine the real things by the soul alone; and then, it seems, after we are dead, as the reasoning shows, not while we live, we shall possess that which we desire, lovers of which we say we are, namely wisdom (66b).

Given all of the problems that life presents for the philosopher, we might conclude that Socrates is looking forward to his impending execution as a great benefit. He goes so far as to argue, in fact, that the philosopher alone deserves the reward that will come to him after his soul is finally free of its impure body. One reason is the philosopher's extreme devotion to wisdom,

${ }^{43}$ Eric Voegelin, The New Science of Politics: An Introduction (Chicago, 1952), pp. 65-6. 
even at the expense of bodily desires. Indeed, his way of life seems to lend support to this conclusion, as Socrates famously lived ascetically so that, presumably, he could ignore as many of the body's demands as possible. But does Socrates truly believe his own rhetoric here or is he simply attempting to shore up his distraught friends at a particularly difficult time? On my reading, Socrates does welcome his own death, seeing it as a necessity, but he seems to be doing much more in the Phaedo than simply encouraging Simmias and Cebes to look forward to their own deaths.

The difficulty in making this case, as with the previous discussion of the Crito, lies in the fact that my interpretation runs counter to the claims made by Socrates in the dialogue. In other words, when Socrates attempts to demonstrate that the soul is immortal, I want to point to the weakness of his arguments in order to suggest that he might not, in fact, believe that the soul is immortal. Nevertheless, in the Phaedo, Socrates has several reasons to hope that others will believe his arguments about the immortality of the soul. These include a desire to calm his friends and to demonstrate the virtues of the philosophic life; after all, he has been arguing that his death is not an evil because the philosopher deserves a reward after death, which hinges on an afterlife in which the philosopher can actually be rewarded. Thus, he puts forward several possible arguments and submits each to questioning. First, he suggests to Cebes that 'the living are born again from the dead' (70a-b). Asking only a few questions - do all beings who have opposites come into being out of their opposites and is death the opposite of life? - Socrates gains assent from Cebes. The trouble, however, is that the points to which he readily agrees do not actually demonstrate the immortality of our souls; instead, they demonstrate that death comes into being out of life. To take the argument further, Socrates provides examples of the connection or similarity between living and dead things, and also gets Cebes to agree that death is akin to sleep. Peter J. Ahrensdorf does a particularly nice job of setting out the problem:

insofar as we are living beings, that is, warm, fully grown beings whose soul and body are combined, and insofar as death transforms us into cold and decayed beings whose soul and body are separate, we no longer exist once our lives have come to an end. And ... insofar as we are thinking beings and insofar as death is a form of sleep for the soul, we no longer truly exist once we have died. ${ }^{44}$

In the end, not even Cebes is particularly convinced of the argument, saying only, '[i]t seems to me ... from our admissions that must of necessity be true' (72a). He has given his agreement to each of the points made by Socrates, but even if he is now convinced about the immortality of the soul, he is disappointed in the sort of immortality that Socrates has put forward.

44 Peter J. Ahrensdorf, The Death of Socrates and the Life of Philosophy: An Interpretation of Plato's Phaedo (Albany, 1995), p. 67. 
The reason that Cebes remains unhappy - and the reason that the dialogue continues with a new argument for the immortality of the soul - is that he desires a particular sort of immortality. Rather than simply being content with the idea that the soul never perishes, Cebes' 'deepest hope is not merely for an everlasting existence but also, and above all, for a perfect and everlasting happiness' ${ }^{45}$ Thus, Cebes suggests that Socrates might put forward another argument in favour of the immortality of the soul, one that he has made in the past. This is the argument that learning is a form of recollection, previously outlined in the Meno (81c). Indeed, as Ahrensdorf rightly highlights, 'the argument that learning is recollection is not only an argument for the immortality of the soul; it is also an argument which seeks to defend the goodness of the life devoted to learning and to the pursuit of wisdom' ${ }^{46}$ At this point in the dialogue, Cebes becomes an ally of Socrates while Simmias takes on the role of an extreme sceptic, arguing not only against the notion that learning is recollection but - in fact - against the idea that learning the truth about these important things is even possible for human beings. While Cebes seems genuinely hopeful that Socrates can persuade him, Simmias seems not to be overly concerned. Of course, in some sense Simmias' sceptical position is an echo of Socrates' own assertion about death and the afterlife in the Apology, quoted above (29a-b). Yet, as Ahrensdorf points out, there is a key difference between the two: while Socrates tells the jurors that he welcomes death out of a genuine curiosity about the afterlife, 'Simmias ... does not regard his ignorance about such matters as the immortality of the soul as an evil and hence ... he believes that he knows all that he needs to know about such matters' ${ }^{47}$ Clearly, this is a notion about which Socrates must disabuse him.

He does so by encouraging Simmias in his belief that he is sufficiently wise, even comparable to Socrates. In each step of the discussion, he equates himself with the young man and argues that they must have acquired all of their knowledge about equality, beauty and goodness before they both were born because they have never seen, in their lives, things that are perfectly equal, beautiful or good. Moving away from the discussion at hand, about recollection, Socrates suggests that they have had this knowledge all of their lives. Having gained acceptance of this point, Socrates goes on to suggest the possibility that all of this knowledge was forgotten when they were born and has since been recollected. Once Simmias agrees with this assessment, Socrates proceeds to challenge his conception of himself as possessing sufficient wisdom by asking him a question he did not anticipate, namely '[w]ere we born knowing, or do we remember afterwards what we had got knowledge of before?' (75e). Simmias admits that he is unable to answer because he does not possess sufficient knowledge of what we were like before birth, when our

\footnotetext{
45 Ibid., p. 68.

${ }^{46}$ Ibid., p. 73.

47 Ibid., pp. 77-8.
} 
souls dwelled amongst the eternal things, precisely the matter that is up for discussion in the Phaedo. While this might be viewed as a cruel trick, it serves its purpose well. 'For, by expressing the wish that all men were wise, Simmias seems to express the wish that he were wise. And by expressing the fear that all men, other than Socrates, are unable to become wise, Simmias seems to express the fear that he may never be able to escape from his ignorance and thereby seems to acknowledge that his ignorance is an evil. ${ }^{48}$ In suggesting that Socrates is wise, however, Simmias presents an objection to any claim that wisdom forever eludes human beings. But he remains reluctant to follow in the philosopher's footsteps, as the conversation is taking place in the very deep shadow of Socrates' impending execution and it is impossible not to be mindful of the consequences of leading a philosophic life. That said, Simmias does not want to think of himself as cowardly, any more than he wanted to think of himself as ignorant; if he abandons the philosophic way of life, he will clearly be doing so because of the fear that he will end his days in the same manner as Socrates. As Ahrensdorf argues, '[h]e must see how important it is for him to know whether or not there is an afterlife in which the philosopher is rewarded for his virtue, that is, for the sacrifices he has made in this life'. ${ }^{49}$ Simmias now turns to a serious consideration of the immortality of the soul in order to mitigate the dangers of philosophy.

The argument that learning is recollection, then, serves less as a way to persuade his interlocutors of the immortality of the soul than to encourage Simmias that he ought to care about the question of whether the soul is immortal. As proof of Socrates' success in this task, Simmias now rejoins the conversation in earnest, putting forward the cogent objection that the existence of souls before birth does not provide evidence that they survive after death (77b). While Socrates argues that Simmias and Cebes will not accept anything he says because, at bottom, they simply fear death and this colours all of their discussion, he proceeds to make a third argument for the soul's permanence, namely that the soul resembles all those things that are immortal and is therefore probably immortal itself. In brief, 'Socrates' third argument for immortality consists of three parts. First, he explains the nature of mortal and immortal beings (78c1-79a11). Then he argues that the soul is similar to what is divine and immortal (79bl-80b7). Finally, he concludes that the soul "is altogether indissoluble or nearly so" $(80 \mathrm{~b} 7-80 \mathrm{~b} 10){ }^{, 50} .^{50}$ While this argument might provide some comfort to his friends at a most difficult time, it is clear that Socrates has not adequately demonstrated that the soul is immortal. Instead, as Ahrensdorf correctly argues, "while the soul may be very similar to what is immortal and

\footnotetext{
48 Ibid., p. 84.

49 Ibid., p. 86.

${ }^{50}$ Ibid., p. 91.
} 
hence may be "nearly" immortal, it is not, in the end, immortal'. ${ }^{51}$ Much as in his discussion with Crito, Socrates again seems to be making arguments that are either suspiciously incomplete or about things he does not actually believe.

Despite their interest in his arguments, their personal devotion to him, and their desire to be persuaded, then, Simmias and Cebes are reluctant to accept what Socrates says, both about the immortality of the soul and about the likelihood that the philosopher will be rewarded after his death. Of course, this might be due in part to the fact that Socrates openly acknowledges that his interlocutors have good reason to doubt his arguments (84d). Why does Socrates so readily admit that his argument is a weak one? Perhaps he notices that Simmias and Cebes are not persuaded, as they are whispering amongst themselves after he concludes his argument. Perhaps he is fearful - despite everything he has said to the contrary - and desires his friends to assist in making a persuasive case about the possibility that his soul will survive his impending death. More likely, though, is that Socrates' style of discussion in the Phaedo is specifically suited to Simmias and Cebes. As Ahrensdorf notes: 'By awakening in them the desire to know that the soul is immortal and by letting them see for themselves the reasons for doubting that the soul is immortal ... Socrates encourages Cebes and Simmias most effectively to examine the question of the immortality of the soul for themselves and on their own. ${ }^{52}$ Given that he will soon be absent from their lives, and given their uncertainty about the virtue of living a life devoted to the search for wisdom, Socrates addresses his primary concern that they will reject the philosophic way of life as a consequence of his execution.

\section{IV \\ Socrates' Last Interlocutors}

Rather than writing a philosophic text and ascribing it to his mentor, Plato chooses to present the character of Socrates in dialogue with people for whom he has specific messages. As David Bolotin notes, 'Socrates' primary intention, it seems, on many or even most occasions was to impart opinions that would be salutary for his particular interlocutors, rather than to teach them what he regarded as the truth. ${ }^{53}$ In the Apology, for example, Plato takes pains to answer the two sets of charges put forward against Socrates, even mimicking the structure used by Aristophanes in the Clouds. Though his principal interlocutor is Meletus, one of his three accusers, Socrates also speaks directly to his jurors about Anytus, his second accuser, and then about an imagined

51 Ibid., p. 99.

52 Ibid., p. 110.

53 David Bolotin, 'The Life of Philosophy and the Immortality of the Soul: An Introduction to Plato's Phaedo', Ancient Philosophy, 7 (1987), p. 39. 
interlocutor. ${ }^{54}$ Zuckert argues that there are two instances in the Apology where Socrates responds to these hypothetical arguments: 'In the first exchange, "one of you" personifies the Just Speech and Socrates, surprisingly perhaps, the Unjust Speech. The second exchange, reversing the order of the Aristophanic model which the first exchange had followed, finds "someone" taking the part of the Unjust Speech while Socrates apparently has the last word in his Just Speech. ${ }^{55}$ In doing so, Plato attempts to use the occasion of Socrates' trial to demonstrate the innocence of philosophy in the face of the charges arrayed against it. As Zuckert argues:

If philosophy leads Socrates to die, willingly, then philosophy does not, as Aristophanes' and the Apology's Unjust Speech did, decree self-preservation the highest good. To complete his Just Speech before the city, to acquit philosophy from the charges leveled against it first by Aristophanes and later by his other accusers, Socrates must actually die; nothing else will do, for philosophy's identification with the thesis of the Unjust Speech can be decisively broken only if there remains no doubt about Socrates' stance toward that thesis. ${ }^{56}$

If readers were unfamiliar with the Clouds, Plato's construction of Socrates' defence would have missed its mark, but given that virtually all would have been well-acquainted with it, the mimicry is particularly useful. The aim of the dialogue is not to prove Socrates' innocence in the face of the various charges, but instead to demonstrate the innocence of philosophy as a way of life. Thus, as Zuckert notes, '[t]he Apology suggests that Socrates could have "gotten off" by being less provocative, but had he done so he would not have mitigated the strong prejudice against philosophy that existed in Athens and elsewhere' ${ }^{57}$ Knowing his audience, Plato crafts the Apology in such a way that Socrates' death is revealed as the noble choice of a moral hero.

This choice is emphasized again in both the Crito and the Phaedo, where Socrates meets with his friends and justifies his decision to accept the fate that awaits him. Again, in both cases, his speeches are crafted for the benefit of his interlocutors. Thus, in the Crito, Socrates presents the argument of the Laws as justification for his decision to remain in prison, despite the fact that these arguments seem hollow and unconvincing. Why, then, does Socrates present them at all and why does he portray them as decisive in his decision not to

${ }^{54}$ Little is known about Socrates' third accuser, Lycon. He is described as quarrelling with Socrates 'on behalf of the orators' (24a) and there is some speculation that, like Anytus, his animosity was based on the relationship between Socrates and his son.

55 Zuckert, 'Rationalism and Political Responsibility', p. 280.

56 Ibid., pp. 293-4. As Zuckert notes, his argument about the structure of the Clouds owes a great deal to that of Leo Strauss (Socrates and Aristophanes (Chicago, 1966)), whose explication of the Aristophanic Socrates is excellent.

${ }^{57}$ Zuckert, 'Rationalism and Political Responsibility', pp. 296-7. 
escape? According to Weinrib, the arguments of the Laws are designed for Crito, who is not himself a philosopher:

Crito and the Laws share the same view of the world, a view based on respect for the views of the many, helping friends and harming enemies, and the avoidance of ridicule and shame ... Although the speeches of Crito and of the Laws are separated by the conversation establishing the two principles, these principles are reflected in neither set of speeches. ${ }^{58}$

Just as Plato uses both the speeches and the actions of the Apology to demonstrate Socrates' commitment to philosophy over self-interest and selfpreservation, he makes a similar case by putting forward and then refuting the argument of the many as presented by Crito. Weinrib argues that 'Crito pleads as a friend, but his arguments show that the disordered randomness of popular morality was not only destructive of law but that it also rendered irrelevent [sic] considerations of real justice' ${ }^{59}$ Crito believes that Socrates ought to escape from prison because it could be arranged for him to do so. This dangerous argument, if followed, suggests that actions are only prohibited if they cannot be successfully accomplished, leading - ultimately - to the selfinterested extreme of the tyrant who does whatever he can (343d-344c). Of course, '[i]t is only because of Crito's unphilosophic nature that Socrates can both sketch a position which is at odds with the opinion of the many and then justify obedience to the law in terms which correspond to the opinion of the many'.60

Rather than reject Crito along with his position, Socrates attempts to use the same argument to refute him. Thus, the Laws - who speak for the many enjoin Crito not to violate principles with which he already agrees and with which Socrates now suggests his agreement. ${ }^{61}$ Socrates is not persuaded by the argument of the Laws, but Crito will be because, in large part, the Laws make the same case for obedience that he attempts to make for disobedience. While the philosopher rejects the argument of the many, he does not dispute

58 Weinrib, 'Obedience to the Law in Plato's Crito', pp. 103-4.

59 Ibid., p. 107.

60 lbid., p. 104.

${ }^{61}$ R.E. Allen, Socrates and Legal Obligation (Minneapolis, 1980), pp. 112-13. I say that Socrates only suggests his agreement because he does not actually admit to being convinced by the arguments of the laws. Instead, he says, 'that these things are what $I$ seem to hear, just as the Corybantes seem to hear the flutes, and this echo of these speeches is booming within me and makes me unable to hear the others' (Plato, Crito 54d). The unusual comparison is noted by Weinrib ('Obedience to the Law in Plato's Crito', p. 101), who argues that 'at the end Socrates indicates that the Laws are not voicing reasoned arguments but are producing the music which accompanies a Corybantic frenzy'. After all, Socrates is not in need of the Corybantic flutes, used to treat fear or other emotional disturbances; rather, Crito is the one who is frantic to rescue Socrates, while the philosopher earlier reported calm sleep even in the face of his impending execution. 
the conclusion put forward by the Laws, for he is committed to obeying the Laws for his own reasons and has already chosen to accept his punishment. In this way, Socrates is able to maintain his friendship with Crito by seeming to accept the argument that his principles explicitly reject. Underlying that acceptance, however, is a refutation of the opinion of the many, as Weinrib notes that '[o]nly the self-abnegation involved in deciding to remain in prison and drink the hemlock could bring home the significance of the enterprise on which Socrates was engaged' ${ }^{62}$ Just as in the Apology, Socrates' actions are necessary to validate the arguments about justice and virtue that he has made throughout his life and to invalidate the charges levied against the philosophic way of life.

The arguments put forward in the Phaedo are substantially different from those of the Apology and the Crito, and they seem not to fit neatly into the position I am sketching here. Indeed, it might be claimed that Socrates suggests he is approaching death in a self-interested manner, emphasizing a position to which he briefly alluded in the Apology. As noted above, Socrates argues there that he does not fear death because he does not know much about it; in addition, he claims that 'no one knows whether death does not even happen to be the greatest of all goods for the human being' (29a). Now, on the day of his death, Socrates directly states not only that philosophers should not fear death, but that they should welcome it $(63 \mathrm{~b}-\mathrm{c})$. As Ahrensdorf says, 'Socrates here reveals to his friends that the philosopher is not only ready or even eager to die but that he devotes his whole life to learning how to die and that he longs throughout his life for nothing but death' ${ }^{63}$ In this discussion with Simmias and Cebes, where Socrates takes as his final subject the immortality of the soul, one might well argue that his position is distinctly self-interested insofar as he argues that he need not fear death because it will be good for him to die. Yet I believe that this would be too narrow a reading of the Phaedo, one that does not delve deeply enough into the arguments that Socrates makes. Instead, I argue that Socrates continues his defence of the philosophic way of life to two friends who are on the verge of rejecting it in the face of the extreme persecution facing philosophers. ${ }^{64}$

${ }^{62}$ Weinrib, 'Obedience to the Law in Plato's Crito', p. 108.

${ }^{63}$ Ahrensdorf, The Death of Socrates, p. 37.

64 This argument runs counter to the one proposed by Xenophon, whose Socrates seeks death in the same manner as the Platonic Socrates but whose motivation is quite different and far less noble (Conversations of Socrates, pp. 42-3). As Gray suggests, Xenophon's Socrates 'had lived a life of perfection so far, an object of admiration for himself and his friends. The future held only the prospect of old age, decay of the senses and the intellect, loss of admiration, lack of repute. If he died easily by hemlock, his reputation would be untarnished in his own eyes and those of his friends, and they would miss him. He decided therefore to use the trial to advertise his perfection and secure that reputation forever' (Gray, 'Xenophon's Defense of Socrates', p. 139). The closest that the Platonic Socrates will come to this position is in noting that he will not flatter his jurors 
More than simply encouraging Simmias and Cebes to think critically during this final conversation, Socrates exhorts everyone present to continue living philosophic lives $(88 \mathrm{a}-\mathrm{c})$. He then proceeds, in his response to the final objections of his interlocutors, to argue that the philosophic life is the best way of life for human beings, regardless of whether there is an afterlife.

While Socrates responds to Simmias' distrust of the particular argument for immortality by encouraging him in his distrust, he responds to [Cebes'] doubt that it is possible for us, in this life, to attain clear knowledge or wisdom about such questions as the fate of the soul by affirming that such knowledge and such wisdom are indeed available to us in this life. ${ }^{65}$

He does so through an elaborate examination of the existence of the divine Ideas, ultimately arguing that they are not able to exist independently of their earthly incarnations. While this argument does not seem to have any bearing on the question of the immortality of the soul, it does speak directly to the question of the goodness of the philosophic way of life. For if the Ideas are not separate and divine beings, existing apart from the world occupied by mortals, it would be possible for the philosopher to attain wisdom concerning those Ideas while alive. In other words, Simmias and Cebes might well be correct about the mortality of the soul and, if so, it might also be correct that there is nothing immortal; in that case, 'wisdom would consist of the greatest possible knowledge of the world as it is revealed to us by our senses' ${ }^{66}$ Of course, through all of this, Socrates states that he is firmly committed to the belief that the soul is immortal and he concludes the discussion with mythical accounts of the soul's existence after death.

In making these statements, I want to contend that, once again, Socrates leaves aside self-interested considerations and focuses instead on achieving some good for others. At a time when he would surely be comforted by simply believing that some great reward awaits him after his death, Socrates instead undermines that position in favour of one that will instil in his surviving friends a desire to continue living philosophically. Yet, in concluding with myths and underscoring his commitment to a belief in the afterlife with his final words ${ }^{67}$ he seems to undermine precisely the position he has been advocating throughout his life. Rather than continuing to urge them to question

because 'I am old and have this name; and whether it is true or false, it is reputed at least that Socrates is distinguished from the many human beings in some way' (34e-35a). While it is a clear allusion to his reputation, something for which he has only contempt in the Crito, it is also quite different from the argument that he desires an early death to avoid declining in esteem due to the vagaries of old age.

${ }^{65}$ Ahrensdorf, The Death of Socrates, p. 186.

66 Ibid., p. 187; cf. Bolotin, 'The Life of Philosophy', p. 53.

67 Immediately before he dies Socrates tells Crito, 'we owe a cock to Asclepios; pay it without fail' (118a), cryptic last words that have been the subject of an overwhelming amount of debate. Joseph Cropsey ('The Dramatic End of Plato's Socrates', Interpretation, 14.2 and 14.3 (May and September 1986), pp. 173-4) suggests that Socrates wanted 
received opinion about the most important things, he now simply tells them to believe in the immortality of the soul, provides a myth rather than an argument for them to consider, and reminds Crito to perform a sacrifice for him. ${ }^{68}$ According to Ahrensdorf, '[b]oth the speeches and deeds of Socrates in the Phaedo appear to demonstrate his piety. The dialogue in which the Athenians execute Socrates for impiety is the dialogue in which Socrates appears to be most pious' ${ }^{99}$ While there continued to be some harassment of individual philosophers in the years after Socrates' death, it is noteworthy that the vocation or lifestyle of philosophy began to be viewed in a far more positive light. ${ }^{70}$ In addition to the fame of Plato and Aristotle, achieved in their own lifetimes, Ahrensdorf points out:

when Aristotle's student Theophrastus was accused of impiety and a law was passed restricting the activities of philosophers in Athens, the Athenians shortly thereafter fined his accuser and repealed the antiphilosophic law so that Theophrastus, who had fled, would return to Athens and live there as before. The Cynic Diogenes and the Stoic Zeno were honored and cherished by the Athenians. And Pyrrho, whose students founded the Sceptics, was appointed the chief priest of Elis. Eventually, the philosophers won renown in the most powerful city in the ancient world, Rome... The reputation of

to thank the god of medicine and healing for a relatively painless death. Nietzsche, however, takes Socrates to mean that he is weary of life and thus owed thanks to Asclepios for his death (Nietzsche, Twilight of the Idols, p. 473); Friedrich Nietzsche, The Gay Science, trans. Walter Kaufmann (New York, 1974), \$340). Ahrensdorf concludes that Socrates was suggesting that he remains uncertain about the fate of his soul and is playing it safe by asking that a sacrifice be performed (The Death of Socrates, pp. 113, 198). A note in the text asserts that this was meant to be a gift to the god of healing on behalf of Plato, who was ill and therefore not present at Socrates' death. I am inclined to agree with this interpretation, as Plato's good health offers the only sort of immortality to Socrates of which he can be certain, one that allows him to live on in the reports of his life and conversations. Ronna Burger writes, 'the Platonic Socrates thus invests his dying words with an appropriate implication of gratitude - Thank god for Plato!' (R. Burger, The Phaedo: A Platonic Labyrinth (New Haven, 1984), p. 216).

${ }^{68}$ In addition to these examples, Socrates provides an argument against suicide, at the outset of the dialogue, that seems straightforwardly pious, namely that human beings are the possessions of the gods who care for them (62c-d). As Bolotin notes, 'just as Cebes would be angry if one of his slaves were to kill himself, without a sign that Cebes wanted him to die, and would even punish him if he could, so might we be punished after death for trying to run away from our divine masters. And if this is true, Socrates continues, it is reasonable that one must not commit suicide until the god sends some necessity, such as the present one, to do so' (Bolotin, 'The Life of Philosophy', p. 42). Of course, Socrates implies to Cebes that he is, in fact, committing suicide - but that he is doing so with the assistance of the god rather than in opposition to the god's commands.

${ }^{69}$ Ahrensdorf, The Death of Socrates, p. 203.

${ }^{70}$ Bolotin, 'The Life of Philosophy', p. 54; Ahrensdorf, The Death of Socrates, p. 202; Sarah Kofman, Socrates: Fictions of a Philosopher, trans. Catherine Porter (Ithaca, 1998), p. 47. 
philosophy grew so great there that such students of philosophy as Scipio Aemilianus Africanus, Cato the Younger and Marcus Aurelius became its leaders. Philosophy, then, which had been an activity engaged in by a small band of persecuted and despised men at the time of Socrates' death, gradually became a subject of study for preeminent statesmen of the ancient world. $^{71}$

In large part, philosophy owes this remarkable reversal of fortune to Plato and his portrayal of Socrates in the dialogues concerning his trial and execution.

In addition, the very end of his life serves as a model for others to emulate; not only does he approach his death with nobility and courage, he also encourages his friends to continue to devote themselves to philosophical inquiry. Earlier in the dialogue, Socrates warns everyone present not to lose faith in reason at the moment they seem most discouraged about reasoned argumentation $(88 \mathrm{a}-\mathrm{c})$. When Simmias and Cebes provide strong arguments against Socrates' claims about the immortality of the soul, all those present despair of ever learning the truth through argumentation, rather than acknowledging that Socrates' arguments might have simply been poor ones or that his interlocutors' speeches might be correct. As Bolotin notes, '[s]o powerful, in other words, is their attachment to the belief in immortality that they would sooner believe that there is no truth in speeches or arguments than that there is no argument for the immortality of the soul'. ${ }^{72}$ In order to bolster these young men at such a precarious time, Socrates encourages them in their belief about immortality. At the same time, however, he leaves them with a series of arguments that highlight the trouble with simply believing in the truth about such an important matter instead of using reason to arrive at it. Indeed, rather than using his final breath to utter some sort of profundity that would undoubtedly be followed blindly as Socrates' true and final teaching, Socrates instead directs his interlocutors back to the unresolved argument they have been having about the soul's immortality. In doing so, he encourages them to continue on the path on which he has set them. ${ }^{73}$ More broadly, in suggesting that Socrates loved Athens, chose to follow its laws and believed in its gods, Plato removes the tainted image of impiety and self-interest from philosophy. Further, by demonstrating that his mentor was dedicated to the pursuit of justice

71 Ahrensdorf, The Death of Socrates, p. 202.

72 Bolotin, 'The Life of Philosophy', p. 55.

${ }^{73}$ Bolotin concludes that Socrates might not have believed in the immortality of the soul, but that Plato avoided directly arguing in favour of this conclusion in the interest of encouraging the pious image of the philosopher in the Phaedo. Further, he argues that 'there may be no better way of helping his friends to think as he did, even on the assumption that he did not believe that his soul was immortal, than the one he actually pursues. By encouraging their desire for an argument that would show the immortality of the soul, Socrates sharpens, at least temporarily, their awareness of their own ignorance regarding this most far-reaching of questions; and he may thereby help awaken, in one or more of them, a desire for knowledge of the whole' (Bolotin, 'The Life of Philosophy', p. 54). 
and wisdom above even his own life - dying in order to benefit others and thereby demonstrating that the kind of life one lives is of far greater importance than its duration - Plato enshrines the character of Socrates as the quintessential moral hero.

Ari Kohen ${ }^{74}$

UNIVERSITY OF NEBRASKA

74 This paper was improved immeasurably by comments on earlier drafts from Jean Cahan, Bill Curtis, Scott Hammond, Sara Kohen, Howard Lubert, Dennis Rasmussen and Ingo Richter, as well as by several on-going discussions about heroism with colleagues, friends and family; finally, for their time, interest and careful attention, special thanks is owed to this paper's anonymous reviewers and to the editor. 